\title{
From the Desk of Editor-in-Chief
}

Alhamdulillah! We feel happy to inform that the Journal of Enam Medical College has been recognised by Bangladesh Medical and Dental Council (BMDC) from its $1^{\text {st }}$ issue (January 2011, Vol 1 No 1). On this occasion, I would like to extend my heartiest congratulations and gratitude to all the teachers of Enam Medical College, contributors, reviewers, members of editorial board, office staff and Chairman and Principal of Enam Medical College. The editorial board commits to continue efforts to maintain the standard of the journal as well as to publish it regularly and timely.

We are highly thankful to the Almighty for the success we have achieved during the last 6 (six) months. Apart from recognition of the journal by BMDC, it has been indexed in four more databases - National Health Library and Documentation Centre, Government of the People's Republic of Bangladesh; Directory of Open Access Journals (DOAJ), Lund University Library, Sweden; Index Copernicus International, Warsaw, Poland and Directory of Research Journal Indexing (DRJI), India. The process of indexing the journal in some other international databases is in progress and we will be continuing our effort to index the journal in many other famous international databases to further increase its visibility to the world scientific community. We have done the creative commons license (CC-BY). This license recommends for maximum dissemination and use of licensed materials within the boundaries of copyright law.

Instructions for authors are updated in this issue. Contributing authors are requested to follow it while preparing their manuscripts for the Journal of Enam Medical College.

A tragic disaster happened very proximate to Enam Medical College on April 24, 2013. Rana Plaza, a nine-storey building collapsed completely costing around 1200 lives, severely injuring thousands and missing an uncertain number of garments workers of different factories located in that building. We do not know how to express our shock and pain. We do not want to mourn at this sort of tragedy any more. We pray to Allah for the eternal peace of the deceased victims in the hereafter life, for early recovery of the injured persons, for compensation of heavy financial losses incurred by this disaster on our already brittle economy. We also express our heartfelt deep sympathy for the bereaved families.

With best wishes.

\section{Prof A. K. M. Rafique Uddin}

Editor-in-Chief 